\title{
Refugee Women, Domestic Labour and Vulnerability in Minawao Camp in Northern Cameroon
}

\author{
Angeline Raymonde NGO ESSOUNGA*, Norah AZIAMIN ASONGU, Ph.D \\ Research Officer, National Centre of Education, Yaounde
}

*Corresponding Author: Angeline Raymonde NGO ESSOUNGA, Research Officer, National Centre of Education, Yaounde, Cameroon

\begin{abstract}
Since 2013, the United Nations High Commission for Refugees (UNHCR) and the State of Cameroon has created a refugee settlement camp in Minawao to manage the influx of Nigerian populations fleeing from Boko Haram insurgencies into Northern Cameroon. In this camp where the populations are initially installed in community shelters and subsequently into family shelters, Nigerians with refugee status are active on a daily basis in various activities which includes though not limited to religious, educational, domestic, and income-generating. This article, which focuses on women's domestic work in Minawao camp, seeks to highlight the activities that constitute domestic work, as well as negative effects of confining women to domestic work in this refugee camp. This study made use of the qualitative approach with the use of interviews, focus group discussions, and direct observation as our data collection methods. Results of the study indicate that programs and projects geared toward improving the living conditions of women in the Minawao camp should be transformative. Besides, breaking down the barriers and stereotypes that keep men and women in traditional gender roles is an element to be included in the supervision of refugees in the Minawao camp.
\end{abstract}

Key Words: Women, refugees, domestic labour, vulnerability, Minawao, Cameroon.

\section{INTRODUCTION}

Domestic labour refers to different activities freely completed within the household. Precisely, this concept is used to definea series of non-remunerated activities carried out in domestic units such as : shopping, cleaning, ironing, cooking, washing up, gardening, physical care of family members (children, husband, elderly persons) and other related work (Delphy 2009,73). This concept is mainly opposed to that of professional work or income generating activities and, leisure. Unlike professional work which belongs to the market economy is visible, domestic labouris invisible, unpaid, is part of the non-market economy, does not appear in any classifications, and includes tasks that are not clearly identified and described (Robert and Toupin, 2018). . Moreover, domestic labour differs from leisure in that, like paid work, it is a series of obligatory or necessary tasks.

Studies on gender issues have revealed that domestic labour is an essential modality of female existence (Adel, 1997), an essential matrix for understanding the situation of women in society (Pfefferkorn, 2011), and a key to understand the place of women and men in society (Maruani, 2013). Definitely, the analysis of domestic labour makes it possible to highlight various aspects of women's lives such as women's experiences in society, inequalities between men and women, social changes inherent in living conditions and the obstacles to women's emancipation, etc. (Dussuet, 2017; Kergoat, 2004; Delphy, 2003).Regarding the experience of women in society, studies carried out on the historiography of women's on the labour market reveals that the confinement of the fairer sex (women) to domestic work for several centuries is at the origin of its marginalization in the labour market (Battagliota, 2000). Women are therefore referred as being inferior to men because they are confined to tasks within the domestic unit that do not benefit of any prestige, while men perform jobs that are accorded respect and prestige in the society, such as the judiciary and the army. Par excellence women are confined in domestic labour which is otherwise invisible and devoid of any social prestige. Although changes in the place of women on the labour market have been noted in recent decades with the entry of women into the business economy, domestic labour remained women's domain; as most of this work is still carried out by the fairer sex. Analyses of the performance of domestic labour within families since women's entry into the labour market in 
general, and studies carried out on the time devoted to domestic work in families where both spouses are in paid employment in particular, have revealed a differentiated and unequal involvement of the genders in domestic labour (Zarca, 1990, Ledoux and Thuilier, 2006, Dumontier and Méda, 2002). These studies show that women participate more in domestic tasks than men. These inequalities are seen in particular in the time spent performing domestic tasks as well as in the number of tasks that men and women regularly perform. Although there is an entry of men into domestic work, women continue to bear the burden of the majority of domestic tasks; many of them are still an almost taboo area for men. Some of these activities that men are gradually getting involved include cooking, washing of dishes, doing laundry and the education of the children (Zarca, 1990, 30). The participation of men in these different tasks is for the most part seen as occasional help. The time spent by women in domestic work far exceeds the time spent by men in these activities. By way of illustration, a study carried out in France has shown in particular that women spend twenty-eight hours of time per week on domestic tasks while men only do eighteen hours of domestic work. These inequalities are observed in particular on a daily basis where, women exercising a paid job or a professional activity experience the double working day combining their paid working day with household work load while men experience single working days (Puech, 2005). Again, it should be noted that domestic work continues to weigh on women despite improved technology and the availability of household appliances, which has led to many transformations. These improved technologies have contributed in reducing the duration and arduousness of household chores and freed women from difficult tasks such as laundry and food preparation (Dumartin, S. and Taché, C, 2001).These various studies have however highlighted the living conditions of women from various angles and have revealed that the inequalities observed in domestic labour remain one of the main obstacles to the emancipation of women (Battagliota, 2001).

This articleis a continuation of studies carried out on women's domestic work. However, it has a particularity in that the authors are interested in domestic work done by a particular female population who are the refugee women in the Minawao camp in Northern Cameroon. This is a female population made up of women of Nigerian nationality, mostly from the states of Bornu and Adamawa, who following the atrocities of the terrorist group Boko Haram in their home towns where insecurity is high, fled to find refuge in the localities of Cameroon where there is relative stability. These women, who have moved in large flows with the men of their communities, were established in the Minawao refugee settlement camp created in 2013 where they constitute $53 \%$ of the refugee population in Cameroon, according to June 2019statistics. This study on women's domestic work is an analysis which permits a deep understanding of the experiences of women in the Minawao camp, and also explores the socio-economic reality in order enable the documentation of the constraints and challenges that refugee women in Minawao face on a daily basis.

\section{MeTHOdOLOGY}

The analysis in this study is built on empirical data and archives. This study made use of the qualitative approach with the use of interviews, and direct observation as the main data collection methods. In 2016, we and other researchers from the National Center for Education, Yaounde visited the refugee camp located at the Northern part of Cameroon, to conduct a study on the vulnerability and survival strategies of the refugee populations. Among the multitude of data collected, data on the place of women in the Minwao camp was included. This data wasobtained from different categories of informants. During our field work carried out in the Minawao refugee settlement camp, we conducted interviews with employees of non-governmental organizations (NGOs) working on the site, partners of the United Nations High Commission for Refugees (UNHCR), and employees of the Cameroonian administration. In addition, focus groups were carried out with four groups of six refugee women each. This gave us an opportunity to study the socio-economic realities and the experiences of the women in the camp. This data was collected in different languages. With the Cameroonian civil service employees and the staff of UNHCR's partner NGOs; data was collected with the use of French language. Giving that the Nigerian refugee women speak neither French nor English data was collected with the use of their mother tongues (Hausa and Kanuri). This was done with the help of translators and interpreters who were introduced to us in the camp. Thus during the exchanges with the women, we asked questions in English which were translated into Hausa or Kanuri by the interpreters according to the ethnic group of the women. Subsequently, the answers given by the women in their mother tongues were translated into English by the refugees who acted as our interpreters. 
The interviews and focus group discussion were taped recorded data, transcribed in English before subjected to a thematic content analysis during which the data relating to domestic work were extracted through the Welf QDA software then categorized and codified. After this analytical work, the data revealed that domestic work is mainly performed by women and, with this sexual division of labour, women are looked upon as a second sex with their work devalued. Consequently, women are exposed different forms of violence such as assault, rape and, do not actively participate in various programs set up in the camp for capacity building and integration into the local labour market.

\section{Results}

\section{A. Domestic Labour in the Minawao Refugee Camp, a Heavy Load for Women.}

\section{A.1. Refugee women in domestic work}

Women engage in domestic work in the Minawao camp, on a daily basis, all without receiving any major male support. Actually, the spouses do not get involved in the management of the household, and the physical care of the members of the family. The main work relating to domestic work carried out in concessions commonly called "lots" are: housework, physical care of family members, and agro-pastoral activities. Housework consists of washing dishes, cleaning the compound, the market, providing fuel (wood) and water, cooking, gardening, preserving food and many other related tasks. These are the most visible aspects because they constitute the bulk of domestic work. The physical care of family members involves taking care of the children, raising them, educating them, watching over their activities, their health and taking care of their husbands. In addition to these activities are the agro-pastoral activities which are carried out in the concessions. In the camp we noticed the cultivation of vegetables and small livestock on the one hand, and on the other hand, agriculture for subsistence carried out on plots of land belonging to the host community, installed in the villages adjacent to the refugee camp, where agricultural activities are carried out in collaboration with the inhabitants of the surrounding villages. This big package of tasks is carried out by women and young boys as evident in the words of this woman:

"We, the women, do all of this, we bring the children to the health centre, we clean the concessions, we cook, we fetch wood and we fetch water. In the blocks where there are water problems, we go to fetch water in the surrounding villages with our children" (Response from a refugee woman during the focus group on July 18, 2016)

It was observed that, women involved in domestic work belong to different generations. We found out that women of all ages (young girls, adolescent girls and adult women), are involved in domestic tasks all day long. We also discovered that there is a certain division of labour based on age. Activities such as providing water and firewood are carried out by young girls and boys. From observation in the camp, wenoticedthatat a particular time of the day, children go to the different water points to fetch water. Adolescent girls and adult women are engaged in various jobs in the concessions. These jobs include; laundry, cleaning the concession, cooking and gardening.

Through the observation of work done by the women, it is obvious that work is carried out in three different spaces: in the domestic unit where the main household activities performed, in the camp where the women have access to various facilities (health care), and outside the camp where they get water, fuel and many other products that are not available in the camp. These spaces are not exclusive. Some activities can be carried out in two different spaces. Thus, the women do not remain only cloistered in the camp. They temporarily leave this space to go to the surrounding villages. For some, these trips outside the camp are very frequent and even daily. Thus, life in the camp is not defined only as life that takes place only on the territory ceded by the Cameroonian government to the UNHCR for the reception of the Nigerian populations who are victims of the abuses of the terrorist group Boko Haram. Some mobility is however restricted in the immediate environment of the camp. The refugees' women sometimes visit the surrounding villages for various domestic activities (search for wood, and farm work); at times they trek for long distances because the existing forests around the camp have already been destroyed by the overexploitation of nature as this camp manager asserts:

"The few forests surrounding the Minawao refugee camp have been destroyed to meet the needs of refugees and neighbouring populations for firewood. The arrival of the refugees has had a considerable impact on the environment. The refugees had to cut a lot trees for firewood in the forest 
on the edge of the camp. Today they are forced to go further" (Interview with the camp manager on July 17, 2016)

While women indulge in domestic activities inside and outside the camp, adult men are practically inactive when they are not called upon for salaried jobs or enrolled in training programs. During an interview conversation a woman asserts that:

"Our husbands have nothing to do all day long. They are not concerned with domestic work" (Response from a refugee woman during the focus group on July 18, 2016)

It is therefore evident that in the Minawao camp, domestic work remains a female sphere. The men stay away; they are not involved in the upkeep of the domestic unit and the care of the children. This situation is quite close to the traditional sexual division of labour in the Kanuri and Hausa peoples (Olawoye et al 2004). It is not characterized by modernity and changes in social gender roles. Thus, although life in the camp brings about social and cultural changes in populations (Corbet, 2008), not all aspects of the culture of populations on the move are subject to change. There are cultural survivals. The peoples carry with them their cultures, habits and customs. While in the camps, they continue to make use of them and reproduce the cultural models of their original communities even in different contexts. Thus, moving from one place to another does not automatically imply a change in lifestyle. It should be noted that the confinement of women to domestic sphere is a cultural trait that persists even in an environment where there are no tasks assigned to men. Thus, it does not respond to a particular form of social division of labour, and testifies to the fact that social structures are not always remodelled according to the contexts, or the new challenges of the community, but reproduced. The sexual division of labour is thus presented as a cultural reality not always connected to the realities experienced by a people. Stereotypes on the role of the women are therefore maintained in their new habitats.

This inactivity of the men is not without consequences on the women, the households and the management of the camp. In fact, the idleness of men is presented as one of the causes of the high birth rate in the camp. And in the Minawao refugee camp, it was revealed that the birth rate is quite high. There are around 55 births per week, according to camp officials. With this high birth rate, women see their parental work increase as it appears in the work of Deville (1977) and Delphy (1970) where, the increase in the number of children is described as an element favouring the surplus workload for women. At the camp level, new births increase vulnerability and create new challenges as stated by this UNHCR worker:

"Here at the camp, we are facing a rapid increase in the population due to births. There are around 55 births per week. This is not without consequences. The camp lives thanks to the donors who are the government of Cameroon and people of good will. Assistance relates to donations received. Given the ever-growing number of refugees in the camp, donations are becoming insufficient. " (Interview with the camp manager on July 17, 2016)

The traditional sexual division of domestic labour persists despite the multiplicity of actions, projects and programs carried out for the protection of refugee women in Minawao. Although programs to improve their living conditions are set up, women continue to be workers who work without rest while men are idle. These social inequalities persist because the various programs initiated do not include components on the transformation of social gender relations. When the programs are set up, their main objective is to improve income, as evidenced by the words of this camp manager who gives details of the programs and projects carried out in favour of women:

"The projects we have for women are geared towards carrying out agricultural activities in collaboration with the host community. It is precisely a matter of creating mixed groups who will plant together and at harvest time will share the produce of the fields. We have also set up a sewing workshop for young girls and plan to set up a bakery" (Interview with the camp manager on July 17, 2016)

Given that the income-generating activities lead to a double working day which is generally described as a situation of vulnerability (Fusulier B. and Drancourt NC 2015), these projects appear as initiatives that will create new forms of insecurity and dysfunctions in the camp.

\section{A.2. Working conditions in domestic labour}

The different activities carried out by women in the camp are usually under difficult conditions. In the majority of cases, women work manually or with rudimentary tools. Systems likely to make 
domestic work less arduous, such as mills for crushing sorghum, ploughs for turning the soil, animals for transporting loads are not offered. To carry out these different tasks, women mainly use their physical strength. They pound the sorghum in mortars, carry the loads on their heads, turn the earth with the hoe, and carry water on their heads. In short, they exhaust themselves in their different tasks.Moreover, in carrying out certain domestic tasks, women are exposed to different forms of violence like assault and rape. Domestic work, as specified above, does not take place only in the Minawao camp; some activities are carried outside the camp, in territories belonging to the host community, and sometimes several kilometres from UNHCR facilities. As part of these different activities: fetching of water, fuel, and construction material (straw for the thatched roof), It was realised in the field that, young girls who go to fetch wood in the nearby forest are frequently pursued and attacked by men wishing to rape them, as this woman declares that: "When our girls go to fetch wood, they are often attacked by men, who even seek to rape them "(Response from a refugee woman during the focus group on July 18, 2016)

In cases where the women are unable to escape or fight back, they are raped as evidenced by these police personnel:

"Women are often raped when they go into the bushes to look for wood or straw. These rapes are most often perpetrated by refugees themselves. Moreover, some of the criminals are imprisoned in Mokolo prison for rape and assault "(Response from a refugee woman during the focus group on July $18,2016)$

With the situations of insecurity inherent in the supply of water and firewood to homes, women occupy a work situation that poses serious risks to their health. Thus, domestic work as performed in this camp is neither healthy nor safe. It exposes women and young girls to the serious consequences of sexual violence. Assaults as well as rapes further have serious consequences on mental health and, on all areas of somatic health where disorders are observed in the short or long term at the gynaecological, neurological, gastrointestinal, muscular levels, articular, cardiovascular, and metabolic as presented in the work of Thomas (2015).

\section{B. Refugee women place in the public sphere, a consequence of the domestic labour}

The refugee camp is a space comparable to a city (Agier 2001). As in all cities, there are private and public spheres. In the camp, we see alleys, schools, hospitals, empty spaces where events are held that can be compared to party places, an area where the offices of the staff that intervene on a daily basis in the supervision of refugees are located. In these different spaces, jobs are offered. In the Minawao refugee camp, jobs are open for nationals (Cameroonians), internationals and refugees. Nationals and internationals are recruited on the basis of their skills. However, the recruitment of refugees is not just a matter of the law of jurisdiction, but is a policy of positive discrimination with quotas put in place to promote the employment of refugees of both sexes. Thus, male and female refugees are part of the workforce employed in the labour market that has developed in Minawao camp. In a conversation with the camp manager about female labour, he confirmed that the domestic labour is a factor that hinders women's access to paid jobs in Minawao camp.

\section{B.1. Domestic responsibilities, a discriminating criterion in recruitments}

In Minawao camp, women work only as community intermediaries with non-governmental organizations working in the protection and empowerment of women. Community intermediaries are recruited among the refugee population to support UNHCR and non-governmental organizations in carrying out their missions. Since these are refugees who live in the camp and know the realities that the refugee population faces on a daily basis, the community relays inform non-governmental organizations about the realities of the community, and they move around the camp to raise awareness and inform the refugee population of actions taken by non-governmental organizations. Thus, community relays play a role of information transmitters and facilitators between non-governmental organizations and refugee populations. For these different jobs mentioned above, the organizations working in the camp only recruit men and single women or widows who do not have a dependent child, as the camp manager declared:

"Women are employed as relays for NGOs because each NGO has its recruitment criteria. They are only recruited on the basis of their autonomy and availability. The women who work as relays for 
NGOs are most of the time, heads of households and therefore alone or widows. Even if they are illiterate, NGOs manage to work with them "(Interview with the camp manager on July 20, 2016)

Regrettably, anyone engaged in parenting work is excluded from these jobs. Thus, domestic work in general and parental work in particular, limits access to community outreach jobs which are not open to the entire working-age population. With this rigorous selection, a large number of the female camp population is excluded from jobs that could improve their living conditions, whereas community relay jobs are among the most stable jobs on the local labour market in Minawao. The jobs offered to women are very important because they are jobs with regular incomes which allow the refugees not only to live on the products distributed monthly but, to also have income which permits them to cover basic needs which humanitarian aid does not meet like the clothing, cooking utensils and even health care.

\section{B.2. Participation in capacity building programs, an activity submitted to the law on domestic labour}

In the Minawao refugee camp, UNHCR and its partners have initiated capacity building programs. These include adult literacy programs and vocational training programs in sewing and carpentry. These different trainings aim to strengthen the capacities of refugees in order to facilitate their empowerment. According to data from the departmental delegation of the Ministry of Basic Education (MINEDUB) which oversees the literacy program, several hundredsof women (approximately 240 women) are participating in this program. However, because of their family responsibilities, women find it difficult to follow the programs assiduously, as the personnel in charge of the MINEDUB literacy program affirms:

"One of the factors limiting the attendance of women in literacy classes is domestic work, particularly the fetching of water. Literacy classes are given in the afternoon. This moment coincides with the time women go to fetch water. So women often arrive latefor training after fetching water")(Interview with the Mayo Tsanaga departmental delegate for basic education, responsible for the literacy program on July 21, 2016 and September 20, 2016)

Fetching of water is not the only domestic task that limits women's participation in capacity building programs. Parenting work also has an impact on women's access to capacity building programs. Most often, when women have to go to the health centre with the children, they spend a lot of time and consequently are unable to attend the training sessions scheduled in the afternoon, as this woman asserts:

"Treatment in the hospital is not easy to get. When I go to the hospital, I spend the whole day before being received by the health personnel. The pace of work for these people is very slow. After that one is often so tired that she cannot do any other work" (Response from a refugee woman during the focus group on July 18, 2016)

Thus, domestic work is an obstacle to capacity building of refugee women and by extension to their empowerment which currently stands as one of the effective humanitarian measures to restore refugees to their dignity.

\section{CONClusion}

Analysis of domestic work among refugee women in Minawao camp revealed that with the perpetuation of traditional roles of femininity and masculinity, women find themselves in precarious living conditions. This vulnerability is observed particularly through the arduousness of domestic work, limited access to salaried jobs granted by UNHCR, exposure to various types of violence such as rape, and low participation in literacy programs and vocational training. This fragile situation persists notwithstanding the establishment of various protection programs for women by the UNHCR, its partners and the State of Cameroon.

With the persistence in the marginalization of womenin the camps, breaking down the barriers and partitions that keep men and women in traditional gender roles is an element to be included in the supervision of refugees. This implies that, to reduce the vulnerability of women, programs and projects initiated by the government and NGOs working with refugee women in the Minawao camp should include components of transformation of gender roles and status rather than creating new forms of insecurity and increase work load for women. The gradual establishment of humanitarian policies aimed at promoting lifestyles that do not respect the traditional standards defined between 
men and women in families and society therefore appear to be an instrument capable of offering refugee women better living conditions. As soon as, the involvement of men in domestic work will encouraged a strong participation of women in decision-making and a marked improvement in their income after massive integration into the local labour market.

\section{REFERENCES}

[1] Adel F., 1997, « Le travail domestique », Insaniyat, Vol 1: 7-19

[2] Ager A., Ager W., et Long L., 1995, «The Differential Experience of Mozambican Refugee Women and Men », Journal of Refugee Studies, Vol8, No.3: 265-287

[3] Agier M., 2014, Un monde de camps, Paris, La Découverte

[4] AgierM., 2002, «Between War and City, Towards an Urban Anthropology of Refugee Camps », Ethnography, Vol. 3, N $\mathrm{N}^{\mathrm{o}}$. 3: 317-341

[5] Battagliota F, 2000, Histoire du travail des femmes, Paris, La Découverte

[6] Battagliota F., 2001, « le travail des femmes: une paradoxale émancipation », Cités, $\mathrm{N}^{\circ} 8$ : 75-85

[7] Bouffartigue P., 2005, «La division sexuée du travail professionnel et domestique : quelques remarques pour une perspective temporelle », Lien social et Politique [En ligne], $\mathrm{N}^{\circ} 54: 13-23$

[8] Cambrézy L., 2001, Réfugiés et exilés, crise des sociétés, crise des territoires, Paris, Editions des archives contemporaines

[9] Corbet A., 2008 ,Nés dans les camps : changements identitaires de la nouvelle génération de réfugiés sahraouis et transformation des camps, Paris, Edition de l'EHESS

[10] Daley P, 1991, «Gender, Displacement and Social Reproduction: Settling Burundi Refugees in Western Tanzania », Journal of Refugee Studies, Vol4, $\mathrm{N}^{\circ} 3$ : 248-266

[11] Delphy C., 2009, L'Ennemi principal, Paris, Editions Syllepse

[12] Delphy C., 2003, « Par où attaquer le partage inégal du travail ménager », Nouvelles Questions Féministes, Vol $22: 47-71$

[13] Deville J.C., 1977, « Activité féminine et fécondité », Économie et statistique, Vol 93, №1 : 51-58

[14] Dumartin, S. et Taché, C, 2001, Equipement des ménages en biens électroménagers, audiovisuels et de communication, Paris, INSEE

[15] Dumontier, F. et Méda, D., 2002, «L'évolution des temps sociaux au travers des enquêtes », Économie et statistique, $\mathrm{Vol} 352 / 353: 3-13$

[16] Dussuet A., 2017, «Le travail domestique: une construction théorique féministe interrompue », Recherches féministes, $\mathrm{Vol} 30, \mathrm{~N}^{\circ} 2: 101-117$

[17] Férreol, G et al, 2002, Dictionnaire de sociologie, Paris, Armand-Colin

[18] Fusulier B. et Drancourt N.C., 2015, «Retour sur l'impossible conciliation travail/famille», Revue Intervention Économique, [En ligne], $\mathrm{N}^{\circ} 53$

[19] Hirata, H., 1993, «Division sexuelle et internationale du travail », Multitudes [En ligne], Vol 2

[20] Kaufmann J.C, 1992, La trame conjugale analyse du couple par son linge, Paris, Nathan

[21] Kergoat, D., 2004, « Division sexuelle du travail et rapports sociaux de sexe », in Helena Hirata, Françoise Laborie, Hélène Le Doare, Danièle Senotier, Dictionnaire critique du féminisme, Paris, PUF : 78-88

[22] Lassailly-Jacob V., 2012, « Les non-dits de l'asile en Afrique subsaharienne », E-migrinter, Vol 9 : 29-46

[23] Ledoux, C. et Thuilier,B, 2006, « Du travail domestique masculin au travail domestique des hommes (analyse quantitative) », Terrains et travaux, $\mathrm{N}^{\circ} 10: 56-76$

[24] Maruani M. (dir), 2013, Travail et genre dans le monde, l'état des savoirs, Paris, La Découverte

[25] Olawoye J. et al, 2004, «Social construction of manhood in Nigeria: Implications for male responsability in reproductive health », African Population Studies, Vol 19, Nㅜㄹ 2: 1-20

[26] Pandolfi M. et Corbet A, 2011, « De l'humanitaire imparfait », Ethnologie française, Vol 41 : 465-472

[27] Pfefferkorn, R., 2011, « Le partage inégal des «tâches ménagères » », Les Cahiers de Framespa, $\mathrm{N}^{\circ} 7$

[28] Puech I., 2005, «Le non-partage du travail domestique » in Margaret Maruani (dir), Femmes, Genre et sociétés, l'état des savoirs, Paris, La Découverte : 176-183

[29] Robert C. et Toupin L. (dir), 2018, Travail invisible. Portraits d'une lutte féministe inachevée, Montréal, Les éditions du remue-ménage

[30] Szczepanikova, A., 2005, «Gender Relations in a Refugee Camp: A Case of Chechens Seeking Asylum in the Czech Republic », Journal of Refugee Studies, Vol 18, Nº 3: 281-298 
[31] Thomas, J.L., 2015, «Les conséquences des violences sexuelles sur la santé physique : revue de la littérature », Revue Française du Dommage du Corporel, N³ : 253-269

[32] Zarca, B.,1990, «La division du travail domestique : poids du passé et tensions au sein du couple », Economie et statistique, $\mathrm{N}^{\circ} 228: 29-40$

\section{AUTHORS' BIOGRAPHY}

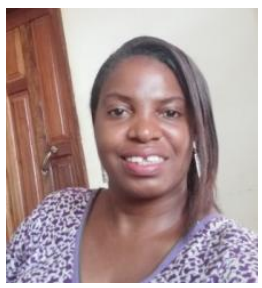

NGO ESSOUNGA Angeline Raymonde, Research Officer at the National Centre of Education in Yaounde and Ph. D student in sociology at the University of Yaounde I, she is particularly interested in research related to gender issues in various domains: migrations, rural and urban settings, labour market, health and sexuality.

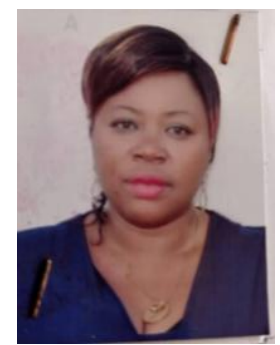

Norah AZIAMIN ASONGU, Research Officer at the National Centre of Education in Yaounde and Phd holder in anthropology with development as specialisation, she is a part time lecturer in the University of Yaounde I and, has been involved in research projects related to gender issues, food production, culture and development

Citation: Angeline Raymonde NGO ESSOUNGA, Norah AZIAMIN ASONGU, Ph.D. " Refugee Women, Domestic Labour and Vulnerability in Minawao Camp in Northern Cameroon" International Journal of Humanities Social Sciences and Education (IJHSSE), vol 8, no. 6, 2021, pp. 72-79. doi: https://doi.org/10.20431/2349-0381.0806011.

Copyright: (C) 2021 Authors. This is an open-access article distributed under the terms of the Creative Commons Attribution License, which permits unrestricted use, distribution, and reproduction in any medium, provided the original author and source are credited. 